\title{
Biochemical Diagnosis of Pheochromocytoma and Paraganglioma
}

\author{
Ying Shen • Liming Cheng \\ Department of Laboratory Medicine, Tongji Hospital, Tongji Medical College, Huazhong \\ University of Science and Technology, Wuhan, P.R. China
}

Authors for correspondence: Ying Shen, Department of Laboratory Medicine, Tongji Hospital, Tongji Medical College, Huazhong University of Science and Technology, Wuhan, Hubei 430030, P.R. China. E-mail: sying830@163.com; Liming Cheng, Department of Laboratory Medicine, Tongji Hospital, Tongji Medical College, Huazhong University of Science and Technology, Wuhan, Hubei 430030, P.R. China. E-mail: chengliming2015@163.com

Doi: http://dx.doi.org/10.15586/paraganglioma.2019.ch2

\begin{abstract}
Pheochromocytoma and paraganglioma are catecholamine-secreting neuroendocrine tumors that arise from chromaffin cells of the adrenal glands and paraganglia. In the absence of timely diagnosis and treatment, overproduction of catecholamines by these tumors can have devastating consequences. Biochemical confirmation of excessive catecholamines and their metabolites is essential for the definitive diagnosis of pheochromocytoma and paraganglioma and proper patient management. This chapter reviews catecholamine biology, biochemical phenotypes, choice of biochemical tests, analytical methods, sampling, storage, and interpretation of the results.
\end{abstract}

Keywords: Catecholamines; Dopamine; Epinephrine; Metanephrine; Norepinephrine

In: Paraganglioma: A Multidisciplinary Approach. Renato Mariani-Costantini (Editor), Codon Publications, Brisbane, Australia. ISBN: 978-0-9944381-7-1; Doi: http://dx.doi.org/10.15586/ paraganglioma.2019

Copyright: The Authors.

Licence: This open access article is licenced under Creative Commons Attribution 4.0 International (CC BY 4.0). https://creativecommons.org/licenses/by-nc/4.0/ 


\section{INTRODUCTION}

Overproduction of catecholamines commonly accompanies the development of pheochromocytoma (PCC) and paraganglioma (PGL). Thus, catecholamines excess provides a powerful biochemical evidence for the diagnosis of PCC/PGL (PPGL) (1-3). Accurate measurement of catecholamines and their metabolites is the first crucial step for the diagnosis of PPGL and patient management (4). With the development of analytical technologies, these biomarkers for PPGL can be determined using several biochemical methods, and the choice of the best method is an issue worthy of discussion (5). An understanding of PPGL biochemical testing, including catecholamine biology, biochemical phenotypes, choice of tests, analytical methods, sampling, storage, and interpretation of results, is of great significance for clinical decision-making.

\section{CATECHOLAMINES BIOLOGY}

Catecholamines, including epinephrine, norepinephrine, and dopamine, constitute a class of chemical neurotransmitters and hormones that occupy important positions in the regulation of physiological processes and are involved in the development of neurological, psychiatric, endocrine, and cardiovascular diseases (6). The metabolism of catecholamines takes place within the cytoplasm of the neuronal or endocrine cells where catecholamines are synthesized. The vesicular stores of catecholamines are in a dynamic equilibrium with the cytosolic pool, and leakage of catecholamines from vesicular granules into the cytoplasm is counterbalanced by inward active sequestration back into stores via vesicular monoamine transporters (7). The metabolism of catecholamines involves primarily two enzymes: monoamine oxidase (MAO) and catechol-O-methyltransferase (COMT), which compete with the vesicular monoamine transporters to inactivate cytoplasmic catecholamines (8). Thus, under resting conditions, catecholamine metabolism is mostly a passive process of vesicular leakage than the active process of exocytosis followed by cellular uptake. Generally, in the metabolic processing of catecholamines, epinephrine (E), norepinephrine (NE), and dopamine (DA) are converted into metanephrine (MN), normetanephrine (NMN), 3,4-dihydroxyphenylglycol (DHPG), 3,4-dihydroxyphenylacetic acid (DOPAC), and 3-methoxytyramine (3-MT) by MAO or COMT, and are terminally metabolized to vanillylmandelic acid (VMA) and homovanillic acid (HVA) (Figure 1). VMA is the end product of E and NE, and HVA is the principal product of DA (9). In addition, DA can also act as the biosynthetic basis for the production of NE under dopamine- $\beta$-hydroxylase (DBH) catalyzation and further conversion to $\mathrm{E}$ under phenylethanolamine-N-methyltransferase (PNMT) catalysis $(6,7,10)$.

Sympathetic nerves contain MAO, but not COMT (4). The substantial production of DHPG from norepinephrine in sympathetic nerves obscures the relatively small increase in DHPG due to tumor cells; thus, DHPG is an insensitive marker of PPGL. Substantial production of VMA from hepatic uptake and metabolism of circulating DHPG and MHPG also make VMA a poor choice. Given that about $80 \%$ of all PPGLs arise from the adrenal medulla (11), catecholamine 


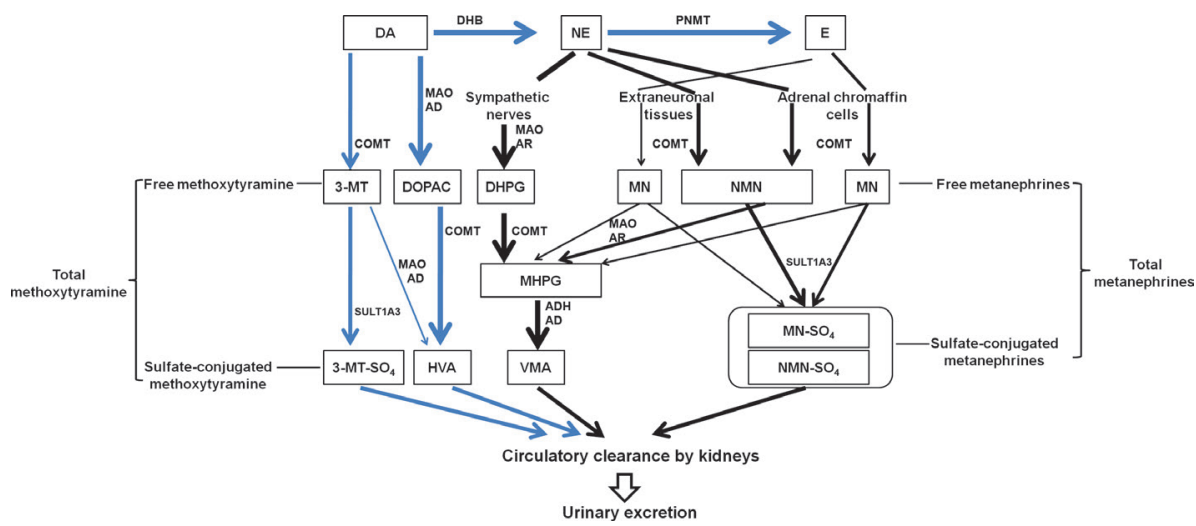

Figure 1 Metabolic pathway of catecholamines. 3-MT, 3-methoxytyamine; 3-MT-SO 3-methoxytyamine sulfate; $\mathrm{ADH}$, alcohol dehydrogenase; $\mathrm{AD}$, aldehyde reductase; $\mathrm{AR}$, aldehyde dehydrogenas; COMT, catechol-O-methyltransferase; DA, dopamine; DBH, dopamine $\beta$-hydroxylase; DHPG, 3,4-dihydroxyphenylglycol; DOPAC, 3,4-dihydroxyphenylacetic acid; E, epinephrine; HVA, homovanillic acid; MAO, monoamine oxidase; MHPG, 3-methoxy-4-hydroxyphenylglycol; $\mathrm{MN}$, metanephrine; $\mathrm{MN}-\mathrm{SO}_{4}$, metanephrine-sulfate; $\mathrm{NE}$, norepinephrine; NMN, normetanephrine, $\mathrm{NMN}-\mathrm{SO}_{4}$, normetanephrine sulfate; PNMT, phenylethanolamine-N-methyltransferase; SULT1A3, sulfotransferase type 1A3; VMA, vanillylmandelic acid.

O-methylation in the adrenal medulla is the predominant source of $\mathrm{MN}$ and NMN, which are produced continuously and independently of catecholamine release. As a result, O-methylated metabolites provide selective and superior biomarkers of catecholamine metabolism in adrenal medullary cells versus neurons. Although tumors that predominantly produce DA due to lack of DBH are occasional, DA metabolism should also be considered for the diagnosis of dopamine-secreting tumors (12). In contrast to sympathetic nerves, adrenal chromaffin cells contain both MAO and COMT. In the adrenal gland, DA is first O-methylated by COMT to 3-MT; subsequently, 3-MT is metabolized by MAO to HVA (9). As MN and NMN, 3-MT is a superior diagnostic biomarker relative to its parent catecholamine and the final metabolic products.

\section{BIOCHEMICAL PHENOTYPES}

The biochemical phenotypes of PPGLs are characterized by the hypersecretion of different combinations of catecholamines. Some PPGLs produce only NE, some secret both NE and DA, some produce both E and NE, and rare tumors secret solely E or DA (4). This can be related to the genetic background of the tumors. In patients with von Hippel-Lindau (VHL) gene mutations, the tumors can be adrenal or extra-adrenal and overproduce only NE, regardless of location. VHL-related PPGLs always present at an early age and are occasionally malignant. PPGLs from patients with mutations in the genes encoding the subunits B and D of succinate dehydrogenase (SDHB and SDHD) are characterized by hypersecretion of DA, either with or without NE. These tumors usually arise in extra-adrenal locations, 
representing $19-28 \%$ of the head and neck PPGLs, can manifest malignant tendency, and present at an early age (13). Generally, the above-mentioned noradrenergic or dopaminergic tumors are partitioned in cluster 1 (including VHL and SDH mutations), whereas the adrenaline-producing tumors are partitioned in cluster 2. The cluster 2 comprises multiple endocrine neoplasia type 2 (MEN 2) and neurofibromatosis type 1 (NF1) patients, who almost always present at comparatively late age with intra-adrenal tumors that are rarely malignant and secrete both $\mathrm{E}$ and NE $(7,14)$. Thus, in addition to disease stratification, the biochemical phenotypes can provide useful information to prioritize gene selection for genetic testing. PPGL patients lacking symptoms of catecholamine excess pose a significant diagnostic challenge. The diagnosis of biochemically silent tumors that do not produce catecholamines is sometimes delayed, with higher risk of advanced metastatic disease. In this respect, SDHB-related extra-adrenal abdominal PPGLs are sometimes biochemically silent $(15,16)$. The determination of circulating chromogranin A (CgA), an acid-soluble protein co-released with catecholamines, may provide an alternative biochemical parameter for the screening of suspected PPGL patients presenting normal catecholamine levels (16).

\section{CHOICE OF TESTS}

The biochemical screening of PPGLs usually involves the measurement of urinary and plasma catecholamines, urinary fractionated metanephrines, plasma free metanephrines, and urinary VMA. Given that PPGL is fatal if undiagnosed, it is important that the biochemical tests used for screening possess a high degree of sensitivity and specificity. The recommended initial test can include the determination of either plasma free metanephrines or urinary fractionated metanephrines, but not of catecholamines themselves $(17,18)$. In fact, unlike catecholamines, which are only secreted episodically and have relatively short half-life, metanephrines as their metabolic intermediates have relatively longer plasma half-lives (5). Furthermore, plasma metanephrine secretion is relatively uninfluenced by sympathoadrenal excitation $(9,19)$. Therefore, either the measurement of plasma free metanephrines or the measurement of urinary fractionated metanephrines provides a highly sensitive assay for PPGLs detection (20-23).

It has been suggested that in young patients, and in outpatients, plasma specimens should be preferred to 24-h urine collection, due to their simpler and more rigorous control (24). Statistical evidence that the measurement of plasma free metanephrines and urinary fractionated metanephrines provides advantages over other tests has been presented in many studies $(21,23-27)$. The measurement of plasma free metanephrines is reported to have a sensitivity of $99 \%$ and a specificity of $89 \%$ (28-30). The sensitivity and specificity reported for the urinary metanephrines assay are lower, that is, 97 and 69\% (31), and those of the plasma catecholamines assay are 84 and $81 \%$, respectively. For urinary catecholamines, the sensitivity is $86 \%$ and the specificity is $88 \%$ (31). The determination of VMA in urine has acceptable specificity (95\%) but relatively low sensitivity (64\%), while total urinary metanephrines have similar specificity but higher sensitivity (i.e., $77 \%$ ) (32). The characteristics of biochemical tests are summarized in Table 1 (33-49). While it is evident that the determination of plasma free metanephrines 


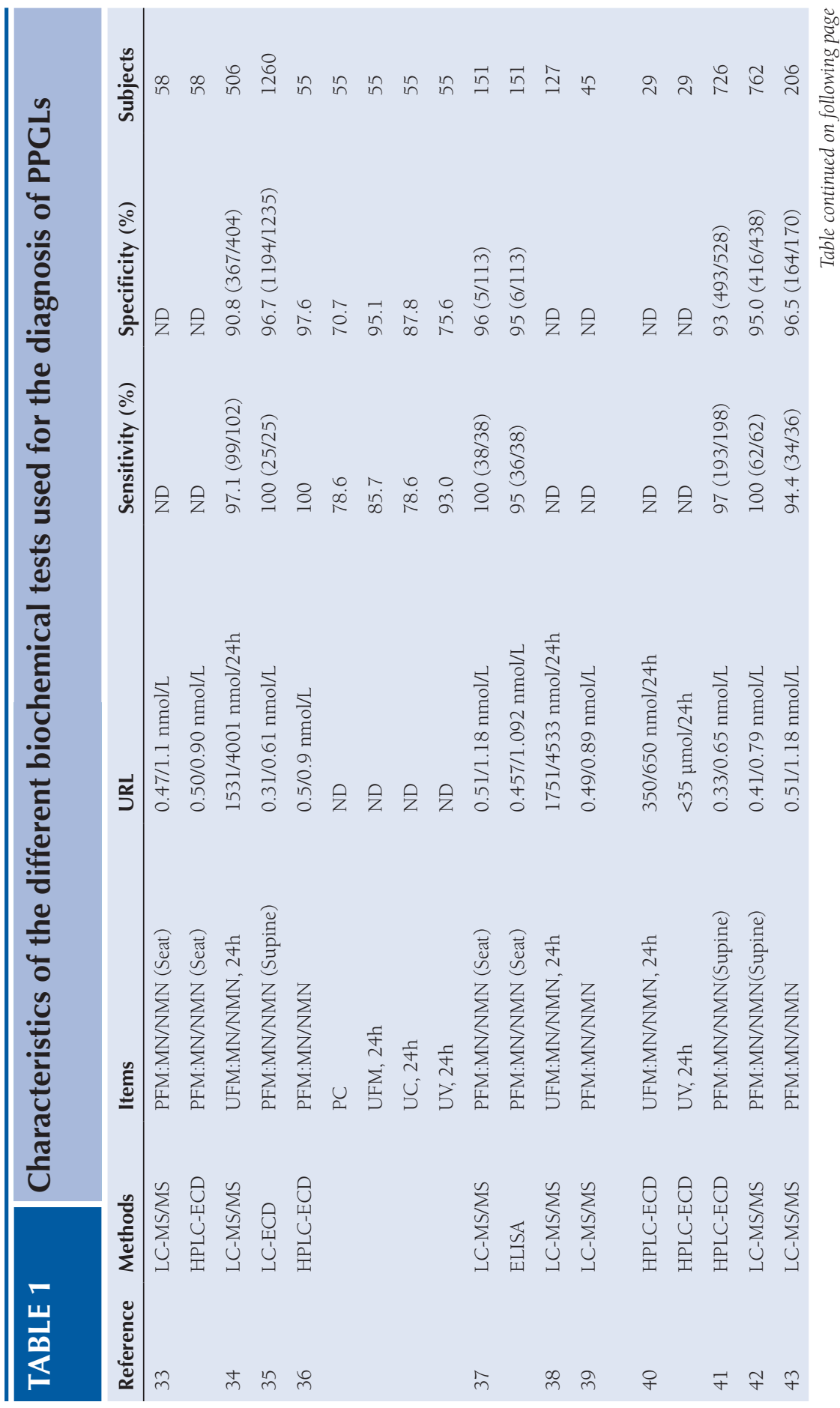




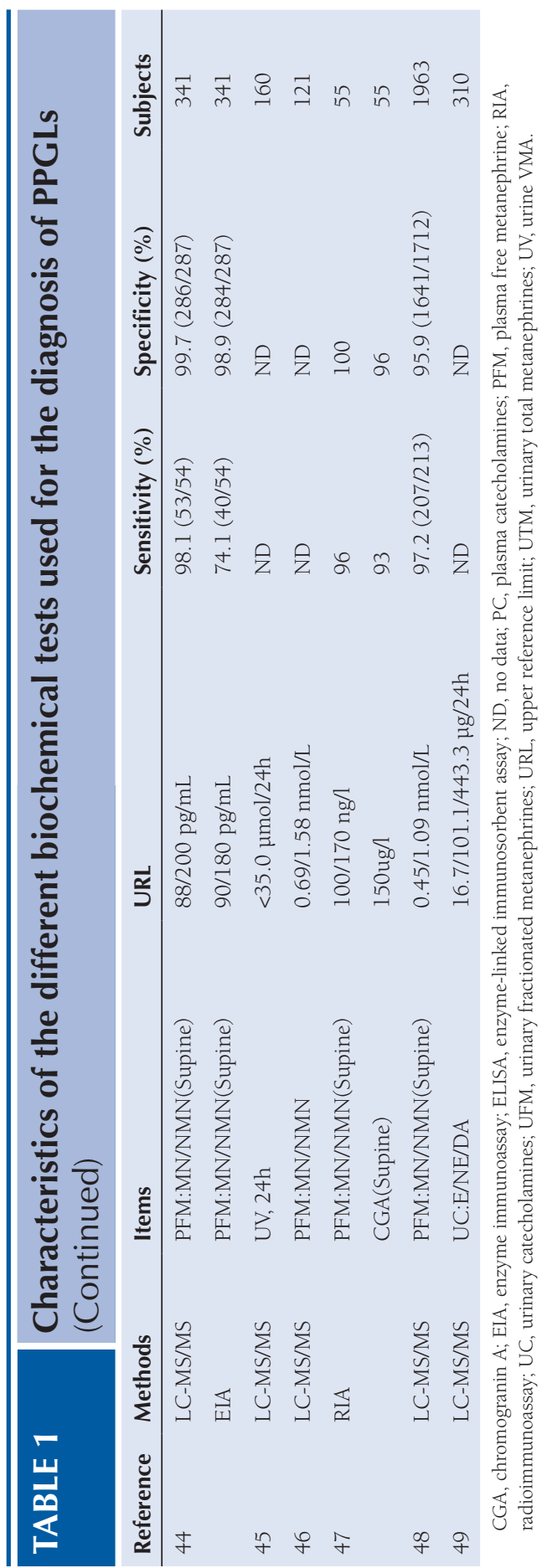


and the determination of urinary fractionated metanephrines are superior methods, the choice of one method over the other is debated (4). A combination of tests could provide a better diagnosis by improving sensitivity and specificity and reducing false positive and false negative results. In addition, the measurement of the plasma concentrations of CgA is sometimes used, especially for silent PPGLs. Importantly, CgA levels are not influenced by the drugs commonly used for PPGLs treatment (20). It is worth noting that emphasis on initial biochemical testing of MN and NMN might make the detection of tumors that produce exclusively DA difficult. Therefore, the O-methylated metabolite of DA, 3-methoxytyramine, should be measured together with MN and NMN for improved accuracy, particularly when screening for SDHB and SDHD-associated PPGLs, often characterized by increased DA, with or without NE increase (4). It is recommended that initial biochemical testing for PPGLs should include the measurement of plasma free metanephrines and/or urinary fractionated metanephrines. The reference intervals vary with the analytical method, and clinical laboratories should establish their own reference intervals.

\section{ANALYTICAL METHODS}

The analytical methods for the evaluation of catecholamines and their metabolites have undergone rapid developments, from simple colorimetric detection to advanced high-performance liquid chromatography (HPLC)-based techniques incorporating electrochemical, fluorometric, and mass spectrometric analyses $(50,51)$. In the early days, colorimetric and fluorometric methods utilized ultraviolet or fluorescent derivatizing agents that reacted with the analytes to produce ultraviolet light or fluorescence $(52,53)$. These methods, however, had poor sensitivity and selectivity, with complicated derivatization processes, and in the 1970s these were quickly replaced by radioenzymatic assays based on enzymatic O-methylation of the catechol ring with a tritium-labeled methyl donor, S-adenosylmethionine (54-56). However, radioenzymatic methods had their own disadvantages, including complexity and length of the procedures and high intra- and inter-laboratory variability, which limited their use in routine clinical laboratory settings.

HPLC coupled with electrochemical (HPLC-ECD) or fluorometric (HPLCFLD) detection is presently the most promising and widely used technique for simultaneous quantification of plasma or urinary catecholamines and their metabolites (57-59). It is superior to gas chromatography coupled with mass spectrometry (GC-MS), which needs time-consuming derivatization to become stable, volatile, and amenable to ionization techniques (60). In addition, compared to radioenzymatic methods, the analytical approaches, including extraction techniques and chromatographic conditions, can be adjusted to eliminate potential endogenous or exogenous interferences. Liquid chromatography coupled with tandem mass spectrometry (LC-MS/MS) provides a powerful analytical system that allows smaller sample volume and shorter run times, offering increased analytical selectivity and sensitivity because detection is based on retention time, molecular mass, and chemical structure, unique to each molecule $(45,49,61)$. LC-MS/MS has become a fundamental tool in next-generation clinical chemistry 
and is the gold standard technique for the determination of catecholamines and their metabolites, although the capital costs of the necessary equipment require economic strength of the laboratory (62).

\section{SAMPLING AND STORAGE CONDITIONS}

Reference intervals should be established from blood samples collected in supine position under fasting condition and after a period of rest for at least 30 min to reduce the influence of sympathetic activation and upright posture on the release of NE and its metabolism to NMN $(42,63-66)$. When reference intervals established from supine sampling are used, samples collected under seated condition yield increased rates of false-positive results. Given the extra time and cost of supine sampling, seated sampling has become widespread in most clinical centers (67). In this situation, samples collected in supine position would contribute to false-negative results, with overall decrease in diagnostic sensitivity (from 99 to 96\%) (63). Therefore, it is important that sampling for the establishment of reference intervals and sampling for actual diagnosis are performed in the same posture, and the supine position is the best. If this cannot be done, the measurement of urinary fractionated metanephrines provides an alternative that is not influenced by sampling posture. For storage, in order to preserve urinary catecholamines and their metabolites, the addition of $\mathrm{HCl}$ to the urine samples is recommended to maintain a low $\mathrm{pH}$ (51). Furthermore, to minimize auto-oxidation and deconjugation, the urine specimens should be kept on ice or refrigerated immediately after collection (68). Catecholamines and VMA in urine are stable at room temperature for only 14 days, while they can be maintained for at least 1 month at $4^{\circ} \mathrm{C}$ or $-80^{\circ} \mathrm{C}(45,49)$, the latter ensuring longer storage $(51)$. However, if the samples are assayed within 1 week, urinary fractionated metanephrines are sufficiently stable at room temperature $(69,70)$. Blood samples should be collected in tubes containing anticoagulant (heparin or ethylenediamine tetraacetic acid, EDTA), stored at $4^{\circ} \mathrm{C}$, and centrifuged within $6 \mathrm{~h}$. Even in the absence of reducing agents, catecholamines are stable in anticoagulated blood for 1 day at $20^{\circ} \mathrm{C}, 2$ days at $4^{\circ} \mathrm{C}, 1$ month at $-20^{\circ} \mathrm{C}$, and up to 1 year at $-70^{\circ} \mathrm{C}$, while plasma free methanephrines can be kept at $4^{\circ} \mathrm{C}$ for 3 days without appreciable degradation and stored at $-80^{\circ} \mathrm{C}$ for longer duration $(70,71)$. Storage conditions should be chosen according to the turnaround time and convenience of the clinical laboratory.

\section{INTERPRETATION OF TEST RESULTS}

The correct interpretation of tests is crucial for accurate PPGLs diagnosis. The most common cause of PPGL overdiagnosis is misinterpretation of borderline results (72), while underdiagnosis most commonly reflects failure to consider the importance of test for PPGL. The overdiagnosis might result in unnecessary 
adrenalectomy and its complications, and the underdiagnosis might lead to adrenal biopsy with hypertensive crisis and longer hospitalization (72). The interpretation of test results requires an understanding of the metabolism of catecholamines and their physiologic variations. Test results should not be simply labeled normal or abnormal on the basis of reference intervals, but rather should be viewed as a continuum from likely normal to likely indicative of PPGLs.

For plasma free metanephrines or urinary fractionated metanephrines, a fourfold upper limit of reference intervals should be set as a threshold likely indicating PPGL (5). Small PPGLs likely result in slight elevation in levels, between the upper limits and the diagnostic level $(32,73)$. In such cases, laboratory results, dynamic tests, and additional markers should be carefully evaluated. Because the initial screening of PPGLs crucially depends on biochemical tests subject to occasional laboratory errors, the tests should be repeated to confirm the result (74). In addition, independent makers of neuroendocrine tumors, such as CgA and neuron-specific enolase, should be considered (75-77).

Interferences from medications and diet should be ruled out. Dietary constituents or drugs can either interfere with the in vitro assay or alter the levels of catecholamines and their metabolites in vivo by affecting the production, release, or metabolism (78). In vitro interferences can be avoided by choice of analytical methods, and in vivo interferences can be minimized by withdrawing specific dietary constituents or drugs before testing. Caffeine, tobacco, fruits, and nuts can influence catecholamine levels and their metabolism and should be avoided overnight before testing (19). Tricyclic antidepressants, phenoxybenzamine monoamine oxidase inhibitors, and other common medications can cause falsepositive elevations (Table 2) (67, 78-83). Notably, L-dopa, used in the treatment of Parkinson's disease, acts as a DA precursor and can cause 3-MT elevations in DA-secreting tumors.

\begin{tabular}{|c|c|c|c|c|}
\hline TABLE 2 & \multicolumn{4}{|c|}{$\begin{array}{l}\text { Medications and diets that may cause false- } \\
\text { positive results of catecholamines and their } \\
\text { metabolites }\end{array}$} \\
\hline Compounds & E & NE & MN & NMN \\
\hline \multicolumn{5}{|l|}{ Drugs } \\
\hline Phenoxybenzamine & - & ++ & - & ++ \\
\hline Tricyclic antidepressants & - & ++ & - & ++ \\
\hline$\beta$-blockers & + & + & + & + \\
\hline Cocaine & ++ & ++ & + & ++ \\
\hline Sympathomimetics & + & + & + & + \\
\hline MAO inhibitors & - & - & ++ & ++ \\
\hline Sulphasalazine & & & - & ++ \\
\hline
\end{tabular}




\begin{tabular}{|c|c|c|c|c|}
\hline \multirow{2}{*}{$\begin{array}{l}\text { TABLE } 2 \\
\text { Compounds }\end{array}$} & \multicolumn{4}{|c|}{$\begin{array}{l}\text { Medications and diets that may cause false- } \\
\text { positive results of catecholamines and their } \\
\text { metabolites (Continued) }\end{array}$} \\
\hline & $\mathbf{E}$ & NE & MN & NMN \\
\hline Levodopa & - & + & + & + \\
\hline Sotalol & unknown & & + & + \\
\hline Acetaminophen & unknown & & - & ++ \\
\hline$\alpha$-Methyldopa & unknown & & - & ++ \\
\hline Busirone & unknown & & ++ & - \\
\hline $\begin{array}{l}\text { Catecholamines and related } \\
\text { drugs }\end{array}$ & ++ & ++ & ++ & ++ \\
\hline \multicolumn{5}{|l|}{ Dietary constituents } \\
\hline Caffeine (coffee, tea) & ++ & ++ & unknown & \\
\hline Nicotine (tobacco) & ++ & ++ & unknown & \\
\hline Theophylline & ++ & ++ & unknown & \\
\hline Alcohol & + & + & unknown & \\
\hline $\begin{array}{l}\text { Catecholamine-rich fruits } \\
\text { and nuts }\end{array}$ & - & + & unknown & \\
\hline
\end{tabular}

In addition, sampling in seated position can result in elevated metanephrines, and this can be easily dealt with by resampling in supine position. If results remain abnormal, normetanephrine levels should be interpreted within the framework of age-adjusted reference intervals and a clonidine suppression test is always helpful (84-86). It is reported that age-adjusted reference intervals minimize false-positives associated with higher normetanephrine plasma concentrations in older patients (87). The clonidine suppression test, based on the principle that clonidine suppresses the normal neurogenically mediated catecholamine release but not that of tumors, can be used to distinguish patients with essential hypertension who have borderline increase in catecholamines and their metabolites from PPGL patients (88). This diagnostic process is illustrated in Figure $2(17,31,89)$.

Caution should also be taken when evaluating patients with chronic kidney disease, especially if on dialysis, as elevated plasma methanephrines are common in this population, even in the absence of PPGL $(90,91)$. Acute myocardial infarction, hypothyroidism, congestive heart failure, and chronic obstructive pulmonary disease can also result in elevated concentrations of catecholamines (92). 


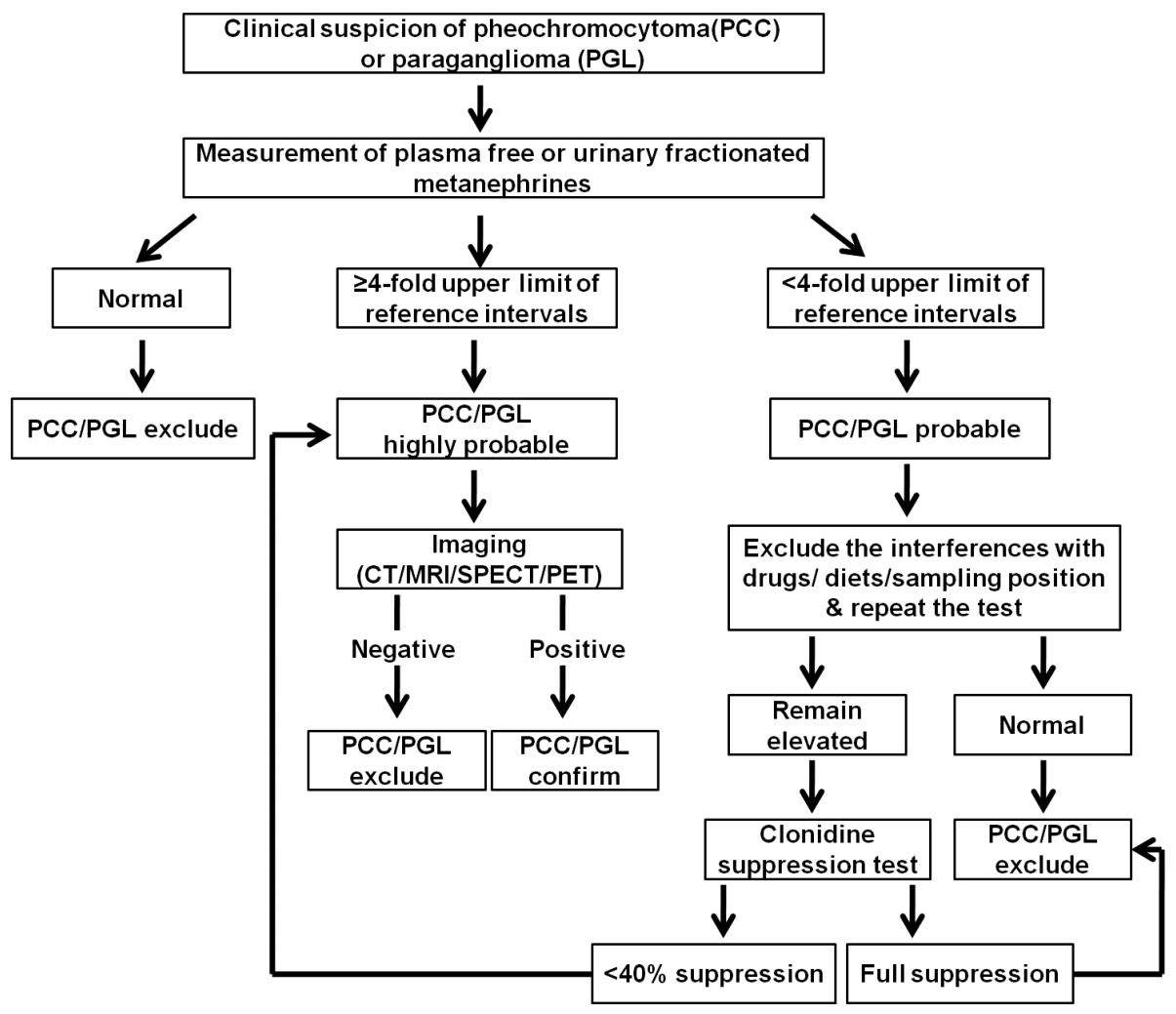

Figure 2 Workflow for the diagnostic evaluation of PPGL patients.

\section{CONCLUSION}

PPGL, characterized by overproduction of catecholamines, is potentially fatal, yet usually surgically curable, cause of endocrine hypertension. Improved understanding of catecholamine release and metabolism, and developments in analytical methodologies have made biochemical testing more reliable, efficient, and crucial for the timely diagnosis of PPGL patients. Reference intervals of plasma free metanephrines are preferentially established using specimens collected via supine fasting sampling, and sampling for actual diagnosis should be performed in the same posture. Although the cutoffs of urinary fractionated metanephrines are not influenced by sampling, whether plasma free metanephrines is better than urinary fractionated metanephrines in terms of diagnostic sensitivity and specificity is a matter of debate; however, plasma sampling is preferable for young persons and outpatients due to its simplicity compared with 24-h urine collection. An increase in plasma free metanephrines or urinary 
fractionated metanephrines beyond the four-fold upper limit of reference interval indicates that PPGL is highly probable. To interpret borderline results, interferences by drugs, diet, and sampling position should be ruled out. However, the standardization of the biochemical testing methods, sampling, and operational procedures should be urgently promoted in different laboratorys for an accurate and timely diagnosis of PPGL.

Acknowledgments: The authors gratefully acknowledge the financial support of the National Natural Science Foundation of China (Grant no. NSFC-81401718).

Conflict of interest: The authors declare no conflicts of interest with respect to research, authorship, and/or publication of this book chapter.

Copyright and permission statement: To the best of our knowledge, the materials included in this chapter do not violate copyright laws. All original sources have been appropriately acknowledged and/or referenced.

\section{REFERENCES}

1. Walther MCM, Keiser HR, Linehan WM. Pheochromocytoma: Evaluation, diagnosis, and treatment. World J Urol. 1999 Feb;17(1):35-9. http://dx.doi.org/10.1007/s003450050102

2. Benn DE, Robinson BG. Pheochromocytoma-quo vadis? Nat Clin Pract Endoc. 2007 May;3(5):377. http://dx.doi.org/10.1038/ncpendmet0498

3. Kudva YC, Sawka AM, Young WF. The laboratory diagnosis of adrenal pheochromocytoma: The Mayo Clinic experience. J Clin Endocrinol Metab. 2003 Oct;88(10):4533-9. http://dx.doi.org/10.1210/ jc. 2003-030720

4. Eisenhofer G, Peitzsch M. Laboratory evaluation of pheochromocytoma and paraganglioma. Clin Chem Dec. 2014;60(12):1486-99. http://dx.doi.org/10.1373/clinchem.2014.224832

5. Tsirlin A, Oo Y, Sharma R., Kansara A, Gliwa A, Banerji MA. Pheochromocytoma: A review. Maturitas. 2014 Mar;77(3):229-38. http://dx.doi.org/10.1016/j.maturitas.2013.12.009

6. Eisenhofer G, Kopin IJ, Goldstein DS. Catecholamine metabolism: A contemporary view with implications for physiology and medicine. Pharmacol Rev. 2004 Sep;56(3):331-49. http://dx.doi. org/10.1124/pr.56.3.1

7. Eisenhofer G, Tishler AS, de Krijger RR. Diagnostic tests and biomarkers for pheochromocytoma and extra-adrenal paraganglioma: From routine laboratory methods to disease stratification. Endocr Pathol. 2012 Mar;23(1):4-14. http://dx.doi.org/10.1007/s12022-011-9188-1

8. Molinoff PB, Axelrod J. Biochemistry of catecholamines. Annu Rev Biochem. 1971 Jan;40:465-500. http://dx.doi.org/10.1146/annurev.bi.40.070171.002341

9. Eisenhofer G, Huynh TT, Hiroi M, Pacak K. Understanding catecholamine metabolism as a guide to the biochemical diagnosis of pheochromocytoma. Rev Endocr Metab Dis. 2001 Aug;2(3):297-311. http://dx.doi.org/10.1023/A:1011572617314

10. Eisenhofer G, Goldstein DS, Kopin IJ, Crout JR. Pheochromocytoma: Rediscovery as a catecholamine-metabolizing tumor. Endocr Pathol. 2003 Sep;14(3):193-212. http://dx.doi.org/10.1007/s12022-003-0012-4

11. Lenders JWM, Eisenhofer G, Mannelli M, Pacak K. Phaeochromocytoma. Lancet. 2005 Aug;366(9486):665-75. http://dx.doi.org/10.1016/S0140-6736(05)67139-5

12. Eisenhofer G, Goldstein DS, Sullivan P, Csako G, Brouwers F, Lai EW, et al. Biochemical and clinical manifestations of dopamine-producing paragangliomas: Utility of plasma methoxytyramine. J Clin Endocr Metab. 2005 Apr;90(4):2068-75. http://dx.doi.org/10.1210/jc.2004-2025 
13. van der Horst-Schrivers ANA, Osinga TE, Kema IP, van der Laan BFAM, Dullaart RPF. Dopamine excess in patients with head and neck paragangliomas. Anticancer Res. 2010 Dec;30(12):5153-5258. [cited 2019 May 13] Available from: http://ar.iiarjournals.org/content/30/12/5153

14. Eisenhofer G, Pacak K, Huynh TT, Qin N, Bratslavsky G, Linehan WM, et al. Catecholamine metabolomic and secretory phenotypes in pheochromocytoma. Endocr-Relat Canc. 2011 Feb;18(1):97-111. http://dx.doi.org/10.1677/ERC-10-0211

15. Koch CA, Vortmeyer AO, Zhuang ZP, Brouwers FM, Pacak K. New insights into the genetics of familial chromaffin cell tumors. Ann N Y Acad Sci. 2002 Sep;970(1):11-28. http://dx.doi.org/10.1111/ j.1749-6632.2002.tb04409.x

16. Timmers HJLM, Kozupa A, Eisenhofer G, Raygada M, Adams KT, Solis D, et al. Clinical presentations, biochemical phenotypes, and genotype-phenotype correlations in patients with succinate dehydrogenase subunit B-associated pheochromocytomas and paragangliomas. J Clin Endocrinol Metab. 2007 Mar;92(3):779-86. http://dx.doi.org/10.1210/jc.2006-2315

17. Kiernan CM, Solórzano CC. Pheochromocytoma and paraganglioma: Diagnosis, genetics, and treatment. Surg Oncol Clin. 2016 Jan;25(1):119-38. http://dx.doi.org/10.1016/j.soc.2015.08.006

18. Manger WM. Diagnosis and management of pheochromocytoma-Recent advances and current concepts. Kidney Int. 2006 Dec;70(104):S30-35. http://dx.doi.org/10.1038/sj.ki.5001974

19. Lenders JWM, Pacak K, Walther MW, Linehan WM, Mannelli M, Friberg P, et al. Biochemical diagnosis of pheochromocytoma: Which test is best? JAMA-J Am Med Assoc. 2002 Mar;287(11):1427-34. http://dx.doi.org/10.1001/jama.287.11.1427

20. Bravo EL, Tagle R. Pheochromocytoma: State-of-the-art and future prospects. Endocr Rev. 2003 Aug;24(4):539-53. http://dx.doi.org/10.1210/er.2002-0013

21. Lenders JWM, Keiser HR, Goldstein DS, Willemsen JJ, Friberg P, Jacobs MC, et al. Plasma metanephrines in the diagnosis of pheochromocytoma. Ann Intern Med. 1995 Jul;123(2):101-9. http://dx.doi. org/10.7326/0003-4819-123-2-199507150-00004

22. Sawka AM, Prebtani APH, Thabane L, Gafni A, Levine M, Young WF Jr. A systematic review of the literature examining the diagnostic efficacy of measurement of fractionated plasma free metanephrines in the biochemical diagnosis of pheochromocytoma. BMC Endocr Disord. 2004 Jun;4:2. http:// dx.doi.org/10.1186/1472-6823-4-2

23. Boyle JG, Davidson DF, Perry CG, Connell MC. Comparison of diagnostic accuracy of urinary free metanephrines, vanillyl mandelic acid, and catecholamines and plasma catecholamines for diagnosis of pheochromocytoma. J Clin Endocr Metab. 2007 Dec;92(12):4602-8. http://dx.doi.org/10.1210/ jc. 2005-2668

24. Bravo EL. Plasma or urinary metanephrines for the diagnosis of pheochromocytoma? That is the question. Ann Intern Med. 1996 Aug;125(4):331-2. http://dx.doi.org/10.7326/0003-4819-125-4199608150-00012

25. Pacak K, Linehan WM, Eisenhofer G, Walther MM, Goldstein MD. Recent advances in genetics, diagnosis, localization, and treatment of pheochromocytoma. Ann Intern Med. 2001 Feb;134(4):315-29. http://dx.doi.org/10.7326/0003-4819-134-4-200102200-00016

26. Eisenhofer G, Lenders JW, Linehan WM, Walther MM, Goldstein DS, Keiser HR. Plasma normetanephrine and metanephrine for detecting pheochromocytoma von Hippel-Lindau disease and multiple endocrine neoplasia type. N Engl J Med. 1999 Jun;340(24):1872-9. http://dx.doi.org/10.1056/ NEJM199906173402404

27. Raber W, Raffesberg W, Bischof M, Scheuba C, Niederle B, Gasic S, et al. Diagnostic efficacy of unconjugated plasma metanephrines for the detection of pheochromocytoma. Arch Intern Med. 2000 Oct;160(19):2957-63. http://dx.doi.org/10.1001/archinte.160.19.2957

28. Lenders JWM, Pacak K, Eisenhofer G. New advances in the biochemical diagnosis of pheochromocytoma moving beyond catecholamines. Ann N Y Acad Sci. 2002 Sep;970:29-40. http://dx.doi. org/10.1111/j.1749-6632.2002.tb04410.x

29. Chen H, Sippel RS, O'Dorisio MS, Vinik AI, Lloyd RV, Pacak K. The North American Neuroendocrine Tumor Society consensus guideline for the diagnosis and management of neuroendocrine tumors: Pheochromocytoma, paraganglioma, and medullary thyroid cancer. Pancreas. 2010 Aug;39(6):77583. http://dx.doi.org/10.1097/MPA.0b013e3181ebb4fo 
30. Unger N, Pitt C, Schmidt IL, Walz MK, Schmid KW, Philipp T, et al. Diagnostic value of various biochemical parameters for the diagnosis of pheochromocytoma in patients with adrenal mass. Eur J Endocrinol. 2006 Mar;154(3):409-17. http://dx.doi.org/10.1530/eje.1.02097

31. Pappachan JM, Raskauskiene D, Sriraman R, Edavalath M, Hanna F. Diagnosis and management of pheochromocytoma: A practical guide to clinicians. Curr Hypertens Rep. 2014 Jul;16(7):442. http:// dx.doi.org/10.1007/s11906-014-0442-z

32. Vora KS, Shah VR. Diagnosis of pheochromocytoma. J Anaesthesiol Clin Pharmacol. 2012 AprJun;28(2):274-6. http://dx.doi.org/10.4103/0970-9185.94931

33. Lagerstedt SA, O'Kane DJ, Singh RJ. Measurement of plasma free metanephrine and normetanephrine by liquid chromatography-tandem mass spectrometry for diagnosis of pheochromocytoma. Clin Chem. 2004 Mar;50(3):603-11. http://dx.doi.org/10.1373/clinchem.2003.024703

34. Perry CG, Sawka AM, Singh R, Thabane L, Bajnarek J, Young WF Jr. The diagnostic efficacy of urinary fractionated metanephrines measured by tandem mass spectrometry in detection of pheochromocytoma. Clin Endocrinol. 2007 May;66(5):703-8. http://dx.doi.org/10.1111/j.13652265.2007.02805.x

35. Václavík J, Stejskal D, Lačňák B, Lazárová M, Jedelský L, Kadalová L, et al. Free plasma metanephrines as a screening test for pheochromocytoma in low-risk patients. J Hypertens. 2007 Jul;25(7):1427-31. http://dx.doi.org/10.1097/HJH.0b013e32813aeb5a

36. Hickman PE, Leong M, Chang J, Wilson SR, McWhinney B. Plasma free metanephrines are superior to urine and plasma catecholamines and urine catecholamine metabolites for the investigation of phaeochromocytoma. Pathology. 2009 Feb;4l(2):173-7. http://dx.doi.org/10.1080/0031302080 2579284

37. Peaston RT, Graham KS, Chambers E, Van der Molen JC, Ball S. Performance of plasma free metanephrines measured by liquid chromatography-tandem mass spectrometry in the diagnosis of pheochromocytoma. Clin Chim Acta. 2012 Apr;411(7-8)546-52. http://dx.doi.org/10.1016/j. cca.2010.01.012

38. Clark ZD, Frank EL. Urinary metanephrines by liquid chromatography tandem mass spectrometry: Using multiple quantification methods to minimize interferences in a high throughput method. J Chromatogr B. 2011 Dec;879(31):3673-80. http://dx.doi.org/10.1016/j.jchromb.2011.10.005

39. Petteys BJ, Graham KS, Parnás ML, Holt C, Frank EL. Performance characteristics of an LC-MS/ MS method for the determination of plasma metanephrines. Clin Chim Acta. 2012 Oct;413 (19-20):1459-1465. http://dx.doi.org/10.1016/j.cca.2012.06.006

40. Davidson DF, Bradshaw N, Perry CG, Londsay R, Freel EM. Urinary free (unconjugated) metadrenalines in different hereditary forms of catecholamine-secreting phaeochromocytoma/paraganglioma. Ann Clin Biochem. 2012 Sep;49(5):486-490. http://dx.doi.org/10.1258/acb.2012.012021

41. Pamporaki C, Därrt R, Bursztynt M, Glöcknert S, Bornsteint SR, Lenders JWM, et al. Plasma-free vs deconjugated metanephrines for diagnosis of Phaeochromocytoma. Clin Endocrinol. 2013 Oct;79(4):476-83. http://dx.doi.org/10.1111/cen.12191

42. Därr R, Pamporaki C, Peitzsch M, Miehle K, Prejbisz A, Peczkowska M, et al. Biochemical diagnosis of phaeochromocytoma using plasma-free normetanephrine, metanephrine and methoxytyramine: Importance of supine sampling under fasting conditions. Clin Endocrinol. 2014 Oct;80(4):478-86. http://dx.doi.org/10.1111/cen.12327

43. Adaway JE, Peitzsch M, Keevil BG. A novel method for the measurement of plasma metanephrines using online solid phase extraction-liquid chromatography tandem mass spectrometry. Ann Clin Biochem. 2015 May;52(3):361-9. http://dx.doi.org/10.1177/0004563214546560

44. Weismann D, Peitzsch M, Raida A, Prejbisz A, Gosk M, Riester A, et al. Measurements of plasma metanephrines by immunoassay vs liquid chromatography with tandem mass spectrometry for diagnosis of Pheochromocytoma. Eur J Endocrinol. 2015 Mar;172(1):251-60. http://dx.doi.org/10.1530/ EJE-14-0730

45. Ying S, Lu J, Tang Q, Guan Q, Sun ZY, Li HJ, et al. Rapid, easy analysis of urinary vanillylmandelic acid for diagnostic testing of pheochromocytoma by liquid chromatography tandem mass spectrometry. J Chromatogr B. 2015 Oct;1002(1):3673-80. http://dx.doi.org/10.1016/j.jchromb.2015.08.013

46. Mui J, Choy KW, Doery JCG. Determination of reference intervals for plasma metanephrine and normetanephrine. Pathology. 2017 Feb;49(S1):S99. http://dx.doi.org/10.1016/j.pathol.2016.12.282 
47. Bílek R, Zelinka T, Vlček P, Duškova J, Michalský D, Novák K, et al. Radioimmunoassay of chromogranin A and free metanephrines in diagnosis of pheochromocytoma. Physiol Res. 2017;66(S3):S397408. [cited 2019 May 13] Available from: https://europepmc.org/abstract/med/28948824

48. Rao D, Peitzsch M, Prejbisz A, Hanus K, Fassnacht M, Beuschlein F, et al. Plasma methoxytyramine: Clinical utility with metanephrines for diagnosis of pheochromocytoma and paraganglioma. Eur J Endocrinol. 2017 Aug;177(1):103-13. http://dx.doi.org/10.1530/EJE-17-0077

49. Shen Y, Cheng LM, Guan Q, Li HJ, Lu J, Wang X. Development and validation of a liquid chromatography tandem mass spectrometry method for the measurement of urinary catecholamines in diagnosis of pheochromocytoma. Biomed Chromatogr. 2017 Nov;31(11):e4003. http://dx.doi.org/10.1002/ bmc. 4003

50. Rosano TG, Swift TA, Hayes LW. Advances in catecholamine and metabolite measurements for diagnosis of pheochromocytoma. Clin Chem. 1991 Oct;37(10):1854-67. [cited 2019 May 13] Available from: http://clinchem.aaccjnls.org/content/37/10/1854

51. Peaston RT, Weinkove C. Measurement of catecholamines and their metabolites. Ann Clin Biochem. 2004 Jan;41(1):17-38. http://dx.doi.org/10.1258/000456304322664663

52. El-Rabbat NA, Omar NM. Colorimetric determination of catecholamines by 2,3,5-triphenyltetrazolium chloride. J Pharm Sci U S. 1978 Jun;67(6):779-81. http://dx.doi.org/10.1002/ jps. 2600670612

53. Manger WM, Steinsland OS, Nahas GG, Wakim KG, Dufton S. Comparison of improved fluorometric methods used to quantitate plasma catecholamines. Clin Chem. 1969 Dec;15(12):1101-1123. [cited 2019 May 13] Available from: http://clinchem.aaccjnls.org/content/15/12/1101

54. Kennedy B, Ziegler MG. A more sensitive and specific radioenzymatic assay for catecholamines. Life Sci. 1990;47(23):2143-53. http://dx.doi.org/10.1016/0024-3205(90)90314-H

55. Peuler JD, Johnson GA. Simultaneous single isotope radioenzymatic assay of plasma norepinephrine, epinephrine and dopamine. Life Sci. 1977 Sep;21(5):625-36. http://dx.doi. org/10.1016/0024-3205(77)90070-4

56. Pussard E, Chaouch A, Said T. Radioimmunoassay of free plasma metanephrines for the diagnosis of catecholamine-producing tumors. Clin Chem Lab Med. 2014 Mar;52(3):437-44. http://dx.doi. org/10.1515/cclm-2013-0406

57. Tsunoda M. Recent advances in methods for the analysis of catecholamines and their metabolites. Anal Bioanal Chem. 2006 Oct;386(3):506-14. http://dx.doi.org/10.1007/s00216-006-0675-z

58. Ueyama J, Kitaichi K, Iwase M, Takagi K, Takagi K, Hasegawa T. Application of ultrafiltration method to measurement of catecholamines in plasma of human and rodents by high-performance liquid chromatography. J Chromatogr B. 2003 Dec;798(1):35-4l. http://dx.doi.org/10.1016/j. jchromb.2003.08.045

59. Huang X, Gui XF, Wang H, Zhang HS. Analysis of catecholamines and related compounds in one whole metabolic pathway with high performance liquid chromatography based on derivatization. Arab J Chem. 2014;Article in press. http://dx.doi.org/10.1016/j.arabjc.2014.11.038

60. Crockett DK, Frank EL, Roberts WL. Rapid analysis of metanephrine and normetanephrine in urine by gas chromatography-mass spectrometry. Clin Chem. 2002 Feb;48(2):332-7. [cited 2019 May 13] Available from: http://clinchem.aaccjnls.org/content/48/2/332

61. Kushnir MM, Urry FM, Frank EL, Robets WL, Shushan B. Analysis of catecholamines in urine by positive-ion electrospray tandem mass spectrometry. Clin Chem. 2002 Feb;48(2):323-31. [cited 2019 May 13] Available from: http://clinchem.aaccjnls.org/content/48/2/323

62. Singh RJ, Eisengofer G. High-throughput, automated, and accurate biochemical screening for pheochromocytoma: Are we there yet? Clin Chem. 2007 Sep;53(9):1565-7. http://dx.doi.org/10.1373/ clinchem.2007.089128

63. Lenders JWM, Willemsen JJ, Eisenhofer G, Ross HA, Pacak K, Timmers Henri JLM, et al. Is supine rest necessary before blood sampling for plasma metanephrines? Clin Chem. 2007 Feb;53(2):352-4. http://dx.doi.org/10.1373/clinchem.2006.076489

64. Casey R, Griffin TP, Wall D, Dennedy MC, Bell M, O'Shea PM. Screening for phaeochromocytoma and paraganglioma: Impact of using supine reference intervals for plasma metanephrines with samples collected from fasted/seated patients. Ann Clin Biochem. 2017 Jan;54(1):170-3. http://dx.doi. org/10.1177/0004563216646395 
65. Eisenhofer G, Därr R, Pamporaki C, Peitzsch M, Bornstein S, Landers JWM. Supine or sitting? Economic and other considerations for use of plasma metanephrines for diagnosis of phaeochromocytoma. Clin Endocrinol. 2015 Mar;82(3):463-4. http://dx.doi.org/10.1111/cen.12602

66. Griffin TP, Casey R, Wall D, Bell M, O'Shea PM. Evaluating the optimum rest period prior to blood collection for fractionated plasma free metanephrines analysis. Pract Lab Med. 2016 Aug;5(1):39_46. http://dx.doi.org/10.1016/j.plabm.2016.05.001

67. LendersJW, Duh QY, Eisenhofer G, Gimenez-Roqueplo AP, Grebe SKG, Murad MH. Pheochromocytoma and paraganglioma: An endocrine society clinical practice guideline. J Clin Endocrinol Metab. 2014 Jun;99(6):1915-42 http://dx.doi.org/10.1210/jc.2014-1498

68. Atuk NO. Pheochromocytoma: Diagnosis, location, and treatment. Hosp Pract. 1983 Apr;18(4):187202. [cited 2019 May 13] Available from: http://nc.yuntsg.com/show.do?q=6404778

69. Willemsen JJ, Ross HA, Lenders JWM, Sweep CGJF. Stability of urinary fractionated metanephrines and catecholamines during collection, shipment, and storage of samples. Clin Chem. 2007 Feb;53(2):268-72. http://dx.doi.org/10.1373/clinchem.2006.075218

70. Boomsma F, Alberts G, van Eijk L, Man in't Veld AJ, Schalekamp MA. Optimal collection and storage conditions for catecholamine measurements in human plasma and urine. Clin Chem. 1993 Nov;39(12):2503-8. Available from: http://clinchem.aaccjnls.org/content/39/12/2503

71. Willemen JJ, Sweep CGJF, Lenders JWM, Ross HA. Stability of plasma free metanephrines during collection and storage as assessed by an optimized HPLC method with electrochemical detection. Clin Chem. 2003 Nov;49(11):1951-3. http://dx.doi.org/10.1373/clinchem.2003.023135

72. Yu R, Nissen NN, Chopra P, Dhall D, Phillips E, Wei M. Diagnosis and treatment of pheochromocytoma in an academic hospital from 1997 to 2007. Am J Med. 2009 Jan;122(1):85-95. http://dx.doi. org/10.1016/j.amjmed.2008.08.021

73. Guerrero MA, Schreinemakers JMJ, Vriens MR, Suh I, Hwang J, Shen WT, et al. Clinical spectrum of pheochromocytoma. J Am Coll Surg. 2009 Dec;209(6):727-32. http://dx.doi.org/10.1016/j. jamcollsurg.2009.09.022

74. Anas SS, Vasikaran SD. An audit of management of patients with borderline increased plasmafree metanephrines. Ann Clin Biochem. 2010 Nov;47(6):554-8. http://dx.doi.org/10.1258/ acb.2010.010131

75. Nobels FRE, Kwekkeboom DJ, Coopmans W, Schoenmakers CHH, Lindemans J, Herder WWD, et al. Chromogranin A as serum marker for neuroendocrine neoplasia: Comparison with neuron-specific enolase and the alpha-subunit of glycoprotein hormones. J Clin Endocr Metab. 1997 Aug;82(8):26228. http://dx.doi.org/10.1210/jcem.82.8.4145

76. Miehle K, Kratzsch J, Lenders J, Kluge R, Paschke R, Koch CA. Adrenal incidentaloma diagnosed as pheochromocytoma by serum chromogranin A and plasma metanephrines. J Endocrinol Invest. 2005 Feb;28(2):1040-2. http://dx.doi.org/10.1007/BF03345347

77. Algerciras-Schimnich A, Preissner CM, Young WF, Singh RJ, Grebe SKG. Plasma chromogranin A or urine fractionated metanephrines follow-up testing improves the diagnostic accuracy of plasma fractionated metanephrines for pheochromocytoma. J Clin Endocr Metab. 2008 Jan;93(1):91-5. http:// dx.doi.org/10.1210/jc.2007-1354

78. Westphal SA. Diagnosis of a pheochromocytoma. Am J Med Sci. 2005 Jan;329(1):18-21. http:// dx.doi.org/10.1097/00000441-200501000-00004

79. Eisenhofer G, Goldstein DS, Walther MM, Friberg P, Lenders JWM, Keiser HR, et al. Biochemical diagnosis of pheochromocytoma: How to distinguish true-from false-positive test results. J Clin Endocr Metab. 2003 Jun;86(6):2656-66. http://dx.doi.org/10.1210/jc.2002-030005

80. Pacak K, Lenders JWM, Eisenhofer G. Current trends in biochemical diagnosis of pheochromocytoma. In: Pheochromocytoma: Diagnosis, localization, and treatment. 1st ed. Oxford, UK: Blackwell Publishing; c2007. p. 72-92. http://dx.doi.org/10.1002/9780470692196.ch7

81. de Jong WHA, Eisenhofer G, editors. Post WJ, Muskiet FAJ, de Vries EGE, Kema IP. Dietary influences on plasma and urinary metanephrines: Implications for diagnosis of catecholamine-producing tumors. J Clin Endorinol Metab. 2009 Aug;94(8):2841-2849. http://dx.doi.org/10.1210/jc.2009-0303

82. de Jong WHA, Post WJ, Kertens MN, de Vries EGE, Kema IP. Elevated urinary free and deconjugated catecholamines after consumption of a catecholamine-rich diet. J Clin Endorinol Metab. 2010 Jun;95(6):2851-5. http://dx.doi.org/10.1210/jc.2009-2589 
83. Neary NM, King KS, Pacak K. Drugs and pheochromocytoma-don't be fooled by every elevated metanephrine. N Engl J Med. 2011 Jun:364(23):2268-70. http://dx.doi.org/10.1056/NEJMc1101502

84. Hodin R, Lubitz C, Phitayakorm R, Stephen A. Diagnosis and management of pheochromocytoma. Curr Prob Surg. 2014 Apr;51(4):151-87. http://dx.doi.org/10.1067/j.cpsurg.2013.12.001

85. Eisenhofer G, Timmers HJ, Lenders JWM, Bornstein SR, Tiebel O, Mannelli M, et al. Age at diagnosis of pheochromocytoma differs according to catecholamine phenotype and tumor location. J Clin Endocr Metab. 2011 Feb;96(2):375-84. http://dx.doi.org/10.1210/jc.2010-1588

86. BravoEL, Tarazi RC, Fouad FM, Vidt DG, Gifford RW. Clonidine-suppression test: A useful aid in the diagnosis of pheochromocytoma. N Engl J Med. 1981 Sep; 305(11):623-626. http://dx.doi. org/10.1056/NEJM198109103051107

87. Eisenhofer G, Lattke P, Herberg M, Siegert G, Qin N, Därr R, et al. Reference intervals for plasma free metanephrines with an age adjustment for normetanephrine for optimized laboratory testing of phaeochromocytoma. Ann Clin Biochem. 2013 Jan;50(1):62-9. http://dx.doi.org/10.1258/ acb.2012.012066

88. McHenry CM, Hunter SJ, McCormick MT, Russell CF, Smye MG, Atkinson AB. Evaluation of the clonidine suppression test in the diagnosis of phaeochromocytoma. J Hum Hypertens. 2011 Jul;25(7):451-6. http://dx.doi.org/10.1038/jhh.2010.78

89. Goldstein DS, Eisenhofer G, Flynn JA, Pacak K. Diagnosis and localization of pheochromocytoma. Hypertension. 2004 May;43(5):907-10. http://dx.doi.org/10.1161/01.HYP.0000125014.56023.b8

90. Laederach K, Weidmann P. Plasma and urinary catecholamines as related to renal function in man. Kidney Int. 1987 Jan;31(1):107-11. http://dx.doi.org/10.1038/ki.1987.16

91. Eisenhofer G, Huysmans F, Pacak K, Walther MM, Sweep FCGJ, Lenders JWM. Plasma metanephrines in renal failure. Kidney Int. 2005 Feb;67(2):668-77. http://dx.doi.org/10.1111/j.1523-1755. 2005.67123.x

92. Wortsman J, Frank S. Cryer PE. Adrenomedullary response to maximal stress in humans. Am J Med. 1984 Nov;77(5):779-84. http://dx.doi.org/10.1016/0002-9343(84)90512-6 
